\title{
KERAGAMAN GENETIK DAN HUBUNGAN KEKERABATAN PADA TIGA JENIS Aquilaria MENGGUNAKAN PENANDA RAPD
}

Genetic Diversity and Genetic Relationship of Three Aquilaria Species Using RAPD Markers

\author{
AYPBC Widyatmoko ${ }^{1}$, Elsih Dian Ariningsih ${ }^{2}$ \& Aniek Prasetyaningsih ${ }^{2}$ \\ ${ }^{1}$ Balai Besar Penelitian Bioteknologi dan Pemuliaan Tanaman Hutan \\ Jl. Palagan Tentara Pelajar Km. 15, Purwobinangun, Pakem, Sleman, Yogyakarta 55582 \\ Telp. (0274) 895954, 896080, Fax. (0274) 896080 \\ ${ }^{2}$ Fakultas Biologi Universitas Kristen Duta Wacana \\ Jl. Dr. Sutomo Yogyakarta
}

Naskah masuk : 5 April 2011 ; Naskah diterima : 5 Juli 2011

\begin{abstract}
Gaharu is an important species of non wood forest product of Aquilaria spp with high economic value. The natural stand has been exploited very intensive. The aim of the study were to investigate level of genetic diversity within and between population, and genetic relationship among 3 species of Aquilaria (namely A. malaccensis, A. beccariana and A. microcarpa) in order to provide genetic information for developing conservation strategy of the species. Samples were collected from 7 populations and analyzed using 26 RAPD primers. Total of 84 polymorpic loci have been obtained from these primers. Mean of genetic diversity within population was 0.225 and between population was 0.284 . The highest genetic diversity within population indicated by A. malaccensis Muara Bungo population. A. malaccensis Berau population has the lowest genetic diversity. The highest genetic distance between populations was between A. microcarpa Samboja and A. beccariana Berau. In contrast, genetic distance between A. microcarpa Berau and A. malaccensis Berau was the lowest (0.017). Based on cluster analysis, the seven populations were divided into 2 groups. The first group consisted of 2 populations of A. malaccensis from Jambi and A. beccariana. The other group consisted of 4 populations of A. malaccensis and A. microcarpa from Kalimantan.
\end{abstract}

\section{Key Words : Aquilaria spp, genetic diversity, RAPD, genetic relationship}

\begin{abstract}
ABSTRAK
Gaharu merupakan salah satu komoditi hasil hutan bukan kayu (HHBK) yang dihasilkan oleh jenisjenis Aquilaria spp dan bernilai ekonomi tinggi. Jenis ini telah mengalami eksploitasi yang intensif sehingga keberadaannya di alam cukup mengkawatirkan. Penelitian ini bertujuan untuk mengetahui tingkat keragaman genetik di dalam dan antar populasi serta untuk mengetahui hubungan kekerabatan antar populasi 3 jenis Aquilaria (yaitu A. malaccensis, A. beccariana dan A. microcarpa) dalam rangka membantu penyusunan strategi konservasi genetik jenis-jenis tersebut. Sampel daun dikumpulkan dari 7 populasi dan dianalisis menggunakan 26 primer RAPD. Total 84 lokus polimorfik dihasilkan dari 26 primer tersebut dengan total pita yang teramplifikasi berukuran antara 220-950 pb.
\end{abstract}


Rata-rata keragaman genetik dalam populasi sebesar 0,225, sedangkan keragaman antar populasi adalah 0,284 . Keragaman genetik di dalam populasi tertinggi terdapat pada populasi $A$. malaccensis Muara Bungo (Jambi), sedangkan nilai keragaman terendah terdapat pada populasi $A$. malaccensis asal Berau. Jarak genetik antar populasi, tertinggi adalah 0,494 yaitu antara populasi $A$. microcarpa (Samboja) dengan populasi $A$. beccariana (Berau). Sebaliknya jarak genetik terendah adalah 0,017, antara populasi $A$. microcarpa (Berau) dengan A. malacensis (Berau). Berdasarkan hasil analisis hubungan kekerabatan, 7 populasi terbagi menjadi 2 kelompok. Kelompok pertama terdiri dari populasi $A$. malacensis dari Jambi ditambah $A$. beccariana, sedangkan kelompok kedua terdiri dari populasi $A$. malaccensis dan $A$. microcarpa yang berasal dari Kalimantan.

\section{Kata Kunci : Aquilaria spp, keragaman genetik, RAPD, hubungan kekerabatan}

\section{PENDAHULUAN}

Gaharu yang juga dikenal sebagai agarwood, eaglewood, atau aloewood merupakan salah satu komoditi hasil hutan bukan kayu (HHBK) yang bernilai ekonomis tinggi. Gaharu diperdagangkan dalam berbagai bentuk, berupa bongkahan, kepingan, ataupun serbuk. Gaharu dikenal memiliki aroma yang khas dan dapat digunakan untuk bahan berbagai keperluan, seperti parfum, hio (pelengkap sembahyang pemeluk agama Budha dan Kong $\mathrm{Hu} \mathrm{Cu}$ ), dan bahan obat-obatan (gangguan ginjal, penghilang stres, sakit perut, asma, hepatitis). Selama ini, sebagian besar produksi gaharu merupakan produksi secara alam. Eksploitasi yang terus menerus tanpa diikuti oleh penanaman kembali mengakibatkan kelestarian jenis-jenis pohon penghasil gaharu seperti Aquilaria spp semakin mengkhawatirkan. Apabila hal ini terus berlanjut akan mengakibatkan hilangnya potensi tegakan Aquilaria spp di alam. Karena kelestarian tegakan Aquilaria yang terancam, CITES (Convention on International Trade of Endangered Species) Wild Flora and Fauna pada APENDIX II CITES memutuskan bahwa jenis $A$. malaccensis termasuk ke dalam daftar jenis tanaman yang terancam punah.

Kegiatan konservasi eks-situ maupun in-situ sangatlah penting untuk dilakukan bagi jenis Aquilaria dalam rangka menyelamatkan potensi genetik yang masih tersisa dan untuk kepentingan pengembangan di masa mendatang. Ketersediaan informasi keragaman genetik untuk jenis Aquilaria spp. akan sangat berguna untuk merencanakan strategi konservasi yang akan dilakukan, khususnya konservasi eks-situ Kegiatan konservasi genetik sebaiknya dilakukan setelah diperoleh informasi mengenai keragaman genetiknya. Untuk memperoleh informasi keragaman genetik secara akurat, salah satu alat yang digunakan adalah penanda DNA. 
Penanda DNA yang sering digunakan untuk analisis keragaman genetik adalah penanda RAPD (Random Amplified Polymorphic DNA) (Welsh dan McClelland, 1990; Wiliams et al., 1990). RAPD merupakan suatu penanda berbasis PCR (Polymerase Chain Reaction) menggunakan primer pendek berukuran 10 basa. Kelebihan penanda ini antara lain relatif mudah untuk dilakukan dengan menggunakan peralatan yang cukup sederhana dan murah. Penelitian keragaman genetik menggunakan penanda RAPD telah dilaporkan pada beberapa jenis tanaman hutan, antara lain Intsia bijuga (Rimbawanto dan Widyatmoko, 2006), Santalum album (Rimbawanto et al., 2006a), Eusideroxylon zwageri (Sulistyawati et al., 2005; Rimbawanto et al., 2006b), Alstonia scholaris (Hartati et al., 2007), Gyrinops versteegii (Widyatmoko et al., 2009) dan Araucaria cunninghamii (Widyatmoko et al., 2010).

Tujuan dari penelitian ini adalah untuk mengetahui tingkat keragaman genetik dan distribusinya pada 7 populasi dari 3 jenis Aquilaria, serta mengetahui hubungan kekerabatan antar populasi tersebut dalam rangka menyediakan informasi guna penyusunan strategi konservasi jenis-jenis tersebut.

\section{BAHAN DAN METODE}

\section{A. Bahan Penelitian}

Materi genetik yang digunakan dalam penelitian ini adalah daun yang berasal dari 80 pohon (famili) 3 jenis Aquilaria (A. malaccensis, A. microcarpa, A. beccariana). Detail nama populasi, jumlah famili per populasi dan jenis disajikan pada Tabel 1.

\section{B. Metode Penelitian}

\section{Ekstraksi DNA dan Prosedur RAPD}

Ekstraksi DNA bertujuan untuk mendapatkan total DNA dari setiap sampel daun yang akan diuji. Sampel daun dari masing-masing individu diekstraksi dengan metode CTAB (Murray dan Thompson, 1980) yang telah dimodifikasi (Shiraishi dan Watanabe, 1995). Seratus mg diekstraksi menggunakan buffer yang terdiri dari psd $\mathrm{H}_{2} \mathrm{O}, 1 \mathrm{M}$ Tris $\mathrm{pH} 9,0,5 \mathrm{M} \mathrm{NaCl}, 0,5 \mathrm{M}$ EDTA, $10 \%$ CTAB dan $\beta$-mercapthoethanol. Hasil ekstraksi DNA dipurifikasi menggunakan GeneClean III Kit (Q-biogene) dan dilarutkan hingga konsentrasi $2,5 \mathrm{ng} / \mu 1$ untuk reaksi PCR.

Reaksi PCR dilakukan dengan volume total $10 \mu \mathrm{l}$ yang mengandung psd $\mathrm{H}_{2} \mathrm{O}, 10 \times$ Stoffel Buffer, dNTP 2,5 mM, $\mathrm{MgCl}_{2}$, AmpliTaq DNA Polimerase $(5 \mathrm{U} / \mu \mathrm{L})$, Primer (1 pmol) dan sampel DNA (10 ng). Primer yang digunakan sebanyak 23 primer dari Operon Technology

Tabel 1. Data sampel yang digunakan pada kegiatan ini

\begin{tabular}{|c|c|c|c|}
\hline No. & Populasi & Jumlah sampel & Species \\
\hline 1 & Muara Bungo (Jambi) & 12 & A. malaccencis \\
\hline 2 & Sarolangun (Jambi) & 12 & A. malaccensis \\
\hline 3 & Samboja (Kaltim) & 12 & A. microcarpa \\
\hline 4 & Sanggau (Kalbar) & 12 & A. malaccensis \\
\hline 5 & Berau (Kaltim) & 12 & A. beccariana \\
\hline 6 & Berau (Kaltim) & 12 & A. microcarpa \\
\hline 7 & Berau (Kaltim) & 8 & A. malaccensis \\
\hline
\end{tabular}


(Tabel 2). Proses PCR diawali dengan pemanasan awal $\left(94^{\circ} \mathrm{C}, 3\right.$ detik) dan inkubasi $\left(95^{\circ} \mathrm{C}, 60\right.$ detik). Tahap selanjutnya adalah amplifikasi sebanyak 45 siklus yang terdiri dari denaturasi $\left(94^{\circ} \mathrm{C}, 30\right.$ detik), penempelan $\left(37^{\circ} \mathrm{C}, 30\right.$ detik) dan pemanjangan $\left(72^{\circ} \mathrm{C}, 90\right.$ detik). Reaksi PCR diakhiri dengan pemanjangan akhir $\left(72^{\circ} \mathrm{C}\right)$ selama 5 menit. Reaksi PCR tersebut dilakukan pada mesin thermocycler GeneAmp PCR System 9700 Applied Biosystems. Hasil amplifikasi PCR dielektroforesis pada 1,5\% gel Agarose, 20X TBE Buffer dan 0,5\% Ethidium bromide selama 2 jam pada $120 \mathrm{~V}$. Hasil elektroforesis difoto menggunakan BIO-RAD Gel Doc ${ }^{\mathrm{TM}} \mathrm{EQ}$.

\section{Analisis Data}

Hasil visualisasi pita-pita DNA diskoring berdasarkan keberadaan pita fragmen DNA hasil amplifikasi dengan klasifikasi "1" bila terdapat pita, dan "0" bila tidak terdapat pita. Hasil skoring dianalisis dengan software program POPGENE 1.32 (Yeh et al., 1999) untuk menghitung nilai keragaman genetik dan jarak genetik berdasarkan Nei's Gene Diversity (1978) dan Nei's Original Measures of Genetic Distance (1978). Analisis klaster mengelompokkan populasi dalam suatu konsep jarak genetik menggunakan metode UPGMA (Unweighted Pair-group Method with Arithmetic Mean). Hasil analisis klaster ditampilkan dalam bentuk dendrogram.

\section{HASIL DAN PEMBAHASAN}

\section{A. Keragaman Genetik}

Dua puluh enam (26) primer RAPD yang telah diseleksi dari 86 primer RAPD digunakan

Tabel 2. Daftar primer yang digunakan dan menghasilkan lokus polimorfik

\begin{tabular}{|l|l|l|c|}
\hline No & Primer & \multicolumn{1}{c|}{$\begin{array}{c}\text { Urutan basa } \\
\left(\mathbf{5}^{\mathbf{-}} \mathbf{- 3}\right)\end{array}$} & Jumlah pita polimorfik \\
\hline 1 & OPA-2 & TGCCGAGCTG & 2 \\
\hline 2 & OPA-4 & AATCGGGCTG & 1 \\
\hline 3 & OPA-10 & GTGATCGCAG & 6 \\
\hline 4 & OPA-11 & CAATCGCCGT & 3 \\
\hline 5 & OPA-12 & TCGGCGATAG & 4 \\
\hline 6 & OPA-13 & CAGCACCCAC & 5 \\
\hline 7 & OPA-16 & AGCCAGCGAA & 8 \\
\hline 8 & OPA-18 & AGGTGACCGT & 3 \\
\hline 9 & OPA-19 & CAAACGTCGG & 2 \\
\hline 10 & OPA-20 & GTTGCGATCC & 3 \\
\hline 11 & OPD-1 & ACCGCGAAG & 2 \\
\hline 12 & OPD-3 & GTCGCCGTCA & 4 \\
\hline 13 & OPD-7 & TTGGCACGGG & 2 \\
\hline 14 & OPG-1 & CTACGGAGGA & 3 \\
\hline 15 & OPG-3 & GAGCCCTCCA & 4 \\
\hline 16 & OPG-4 & AGCGTGTCTG & 4 \\
\hline 17 & OPG-6 & GTGCCTAACC & 3 \\
\hline 18 & OPG-7 & GAACCTGCGG & 3 \\
\hline 19 & OPG-8 & TCACGTCCAC & 4 \\
\hline 20 & OPG-11 & TGCCCGTCGT & 2 \\
\hline 21 & OPG-12 & CAGCTCACGA & 4 \\
\hline 22 & OPG-15 & ACTGGGACTC & 1 \\
\hline 23 & OPG-18 & GGCTCATGTG & 2 \\
\hline 24 & OPG-19 & GTCAGGGCAA & 1 \\
\hline 25 & OPQ-3 & GGTCACCTCA & \\
\hline 26 & OPQ-6 & GAGCGCCTTG & \\
\hline & & Jumlah & \\
\hline
\end{tabular}


untuk menganalisa keragaman genetik 7 populasi Aquilaria spp. Pita DNA yang digunakan untuk analisis berukuran 220-950 pb (pasang basa). Jumlah fragmen atau pita polimorfik yang dihasilkan berkisar antara 1 (OPA-4, OPD-3, OPG-19, dan OPQ-6) sampai dengan 8 (OPA18). Total terdapat 84 lokus yang dihasilkan dari 26 primer tersebut. Nama primer, urutan basa dan jumlah pita polimorfik yang dihasilkan dapat dilihat pada Tabel 2.

Berdasarkan Nei's Gene Diversity (Nei, 1978), keragaman genetik di dalam populasi dari 7 populasi Aquilaria spp bervariasi antara 0,1800,285 . Keragaman genetik terbesar dimiliki oleh populasi A. malaccensis asal Muara Bungo (Jambi; 0,285), sedangkan yang terendah dimiliki oleh populasi $A$. malaccensis asal Berau yaitu sebesar 0,089 (Tabel 3).

Keragaman genetik pada populasi $A$. malaccensis di Jambi lebih tinggi yang berasal dari Kabupaten Muara Bungo dibandingkan dengan di Sarolangun. Hal ini disebabkan karena kemungkinan materi yang digunakan untuk Kabupaten Muara Bungo berasal dari persemaian yang merupakan kumpulan benih yang berasal dari beberapa lokasi atau jumlah individunya yang lebih banyak dibandingkan dengan Kabupaten Sarolangun.

Keragaman genetik A. malaccensis di Berau lebih rendah dibandingkan populasi-populasi yang lain, khususnya yang berasal dari wilayah yang sama. Hal ini kemungkinan disebabkan oleh 2 hal, yaitu jumlah individu awal yang lebih sedikit dibandingkan jenis yang lain, atau terjadinya eksploitasi yang lebih intensif pada jenis ini di Berau sehingga jumlah individunya jauh berkurang.

Rata-rata keragaman genetik Aquilaria di dalam populasi yaitu 0,225. Angka ini lebih besar daripada rata-rata keragaman genetik baik untuk kelompok jenis tropis dan konifer, yaitu 0,211 dan 0,207 yang telah dilaporkan oleh Hamrick (1989). Dibandingkan dengan beberapa jenis tropis yang lain (Araucaria cunninghamii, Instia bijuga, Alstonia scholaris, Eusideroxylon swageri, Gyrinops versteegii dan Santalum album), keragaman Aquilaria spp ini relatif lebih rendah. Hal ini mengidentifikasikan intensitas penebangan yang lebih besar pada Aquilaria dibandingkan jenis yang lain.

Tabel 3. Nilai keragaman genetik di dalam populasi (diagonal) dan antar populasi (di bawah diagonal) dari 7 populasi Aquilaria $s p$.

\begin{tabular}{|c|c|c|c|c|c|c|c|}
\hline Populasi & $\mathbf{1}$ & $\mathbf{2}$ & $\mathbf{3}$ & $\mathbf{4}$ & $\mathbf{5}$ & $\mathbf{6}$ & $\mathbf{7}$ \\
\hline 1 & $\mathbf{0 , 2 8 5}$ & & & & & & \\
\hline 2 & 0,030 & $\mathbf{0 , 2 4 0}$ & & & & & \\
\hline 3 & 0,368 & 0,442 & $\mathbf{0 , 2 0 9}$ & & & & \\
\hline 4 & 0,322 & 0,405 & 0,037 & $\mathbf{0 , 2 2 8}$ & & & \\
\hline 5 & 0,239 & 0,254 & 0,494 & 0,488 & $\mathbf{0 , 2 3 2}$ & & \\
\hline 6 & 0,298 & 0,396 & 0,055 & 0,040 & 0,492 & $\mathbf{0 , 2 0 5}$ & \\
\hline 7 & 0,305 & 0,404 & 0,075 & 0,660 & 0,476 & 0,017 & $\mathbf{0 , 1 8 0}$ \\
\hline
\end{tabular}

Keterangan : 1. A. malaccensis (Muara Bungo, Jambi),

2. A. malaccensis (Sorolangun, Jambi),

3. A. microcarpa (Samboja, Kaltim),

4. A. malaccensis (Sanggau, Kalbar),

5. A. beccariana (Berau, Kaltim),

6. A. microcarpa (Berau, Kaltim),

7. A. malaccensis (Berau, Kaltim) 
Pada hasil analisis jarak genetik antarpopulasi, tertinggi adalah 0,494 yaitu antara populasi $A$. microcarpa Samboja dengan populasi $A$. beccariana Berau. Hal ini terjadi karena perbedaan jenis dan jarak geografis dari kedua populasi. Sebaliknya jarak genetik terendah adalah antara populasi $A$. microcarpa Berau dengan populasi A. malaccensis Berau, yaitu 0,017 (Tabel 3). Walaupun kedua populasi ini memiliki jenis yang berbeda, tetapi karena kedua populasi tersebut hidup pada lingkungan yang sama maka mempunyai hubungan yang sangat dekat. Kedekatan antar kedua species ini juga dibuktikan dengan dekatnya jarak genetik antara populasi $A$. microcarpa Samboja dan $A$. malaccensis di Sanggau Kalimantan Barat, yaitu 0,037. Walaupun kedua populasi berada pada populasi dengan jarak geografis yang cukup jauh, tetapi keduanya mempunyai jarak genetik yang sangat dekat. Hal ini membuktikan bahwa $A$. malaccensis dan A. microcarpa yang secara morfologis hanya bisa dibedakan dengan karakter generatifnya (bunga dan buah) ternyata memiliki hubungan genetik yang sangat dekat. Jarak genetik antar populasi dari kedua jenis tersebut lebih rendah dari jarak genetik dari populasi untuk jenis yang sama yaitu 0,660 untuk jarak genetik antar populasi A. malaccensis dan 0,055 untuk jarak genetik antar populasi $A$. microcarpa di Kalimantan.

Rata-rata jarak genetik antar populasi dari tujuh populasi Aquilaria spp adalah 0,284, angka ini jauh lebih besar daripada jarak genetik antar populasi dari keenam jenis tropis di atas. Besarnya nilai jarak genetik antar populasi disebabkan karena materi genetik yang digunakan berasal dari jenis yang berbeda, sehingga mempunyai jarak genetik yang cukup jauh. Populasi yang berasal dari pulau yang berbeda juga menyebabkan tingginya jarak genetik antar populasi tersebut.

\section{B. Hubungan Kekerabatan Antar Populasi}

Berdasarkan informasi nilai jarak genetik antar-populasi, dendogram disusun menggunakan metode UPGMA untuk mengetahui hubungan kekerabatan antar 7 populasi Aquilaria spp. Hasil dendogram berdasarkan jarak genetik Nei's (1978) tersebut membagi tujuh populasi Aquilaria spp menjadi dua kelompok besar. Kelompok pertama terdiri dari populasi $A$. malaccensis Muara Bungo (Jambi), $A$. malaccensis Sarolangun (Jambi) dan $A$. beccariana Berau. Kelompok kedua terdiri dari

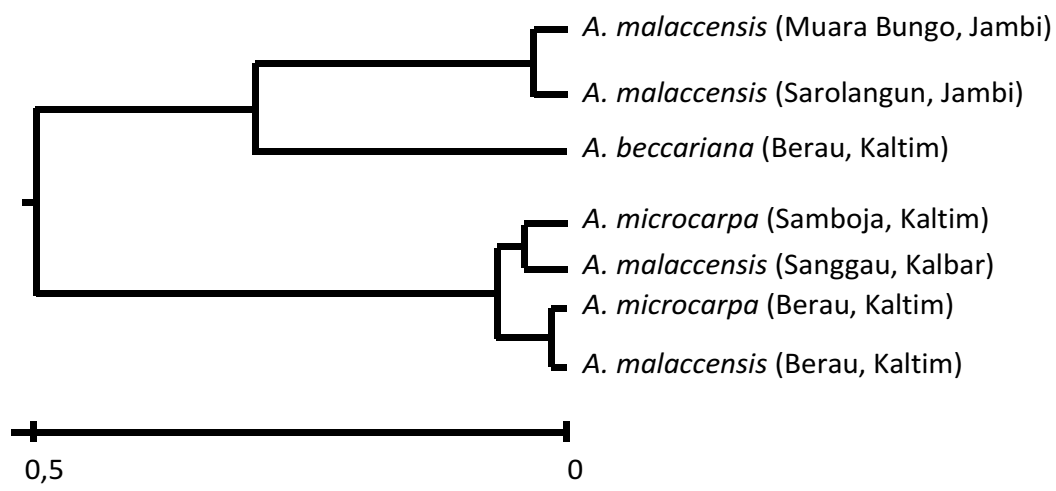

Gambar 1. Dendogram hubungan kekerabatan antara 7 populasi Aquilaria spp berdasarkan jarak genetik Nei's (1978) 
populasi A. microcarpa Samboja, A. malaccensis Sanggau, $A$. malaccensis Berau dan $A$. microcarpa Berau.

Gambar 1 menunjukkan adanya pengelompokan yang jelas untuk $A$. malaccensis dan $A$. microcarpa yang berasal dari pulau yang berbeda. Pengecualian terjadi untuk $A$. beccariana yang berasal dari Berau, Kaltim. Populasi ini bergabung dengan A. malaccensis dari Jambi (Sumatera).

Pengelompokan berdasar dendrogram tersebut memperlihatkan hubungan yang khusus antara $A$. malaccensis dan $A$. microcarpa. Pengelompokan kedua jenis tersebut lebih pada jarak geografis dibandingkan dengan kedekatan jenisnya. Kedua spesies yang berasal dari lokasi yang sama (Berau, Kaltim) mempunyai hubungan kekerabatan yang sangat dekat dibandingkan dengan populasi dari jenis yang sama yang lokasi geografisnya lebih jauh. A. microcarpa dari Samboja dan $A$. malaccensis dari Sanggau, walaupun berasal dari propinsi yang berbeda, mempunyai jarak genetik yang relatif dekat. Pengelompokan kedua jenis tersebut kemungkinan disebabkan karena dekatnya hubungan kekerabatan dimana kedua jenis tersebut hanya bisa dibedakan dengan karakter generatifnya, sehingga mudah sekali untuk terjadi perkawinan silang antar jenis (inter-species hybrid). Dengan demikian, kemungkinan sampel yang digunakan tidaklah murni dari kedua jenis, tetapi sudah merupakan hibrid alami. Kedekatan jarak genetik A. beccariana asal Berau dengan $A$. malaccensis asal Jambi agak susah untuk dijelaskan karena hanya ada 1 populasi $A$. beccariana yang digunakan dalam penelitian ini, sehingga tidak ada pembandingnya. Kemungkinan dari kondisi ini adalah asal-usul terjadinya $A$. beccariana adalah di Sumatera dan struktur tersebut tetap terjaga sehingga keseluruhan atau sebagian besar $A$. beccariana mempunyai kedekatan struktur genetik dengan jenis Aquilaria di Sumatera. Kemungkinan tersebut perlu dibuktikan dengan menambahkan beberapa populasi $A$. beccariana baik dari Sumatera maupun Kalimantan.

Pengelompokan dari populasi ketiga jenis Aquilaria tersebut yang tidak membentuk struktur homofili (homophyly) dapat disebabkan oleh beberapa hal yaitu terjadinya perkawinan antar jenis (hibridisasi) seperti yang disebut di atas, jumlah sampel per populasi yang terlalu sedikit (8-12 individu per populasi) dan primer RAPD yang digunakan kemungkinan tidak dapat menggambarkan struktur genetik level intra spesies. Carrio et al. (2010) melaporkan kecilnya struktur monofili pada pada tiga jenis endemik Antirrhinum yang disebabkan karena terjadinya hibridisasi antar ketiga jenis tersebut. Dengan menambah jumlah sampel per populasi dan primer RAPD yang digunakan, disertai dengan pemilihan individu yang murni dari satu jenis (bukan hibrid), kemungkinan pengelompokan per jenis akan lebih kelihatan.

\section{Implikasinya terhadap program konser- vasi ketiga jenis Aquilaria}

Penentuan strategi konservasi maupun pemuliaan suatu jenis tanaman hutan memerlukan informasi keragaman genetik dari jenis tersebut agar dapat dilaksanakan secara efektif dan efisien. Indrioko (1996) menyebutkan bahwa keragaman genetik berguna untuk mengetahui asal-usul jenis pohon tertentu, menentukan strategi pemuliaan, dan menentukan strategi konservasi genetik. 
Strategi konservasi yang perlu diterapkan untuk ketiga jenis Aquilaria di atas perlu mempertimbangkan informasi keragaman genetik dari ketiga jenis tersebut. Rata-rata keragaman genetik dalam populasi sebesar 0,225 , menunjukkan masih tingginya keragaman genetik dalam populasi dari individu-individu dalam populasi yang masih tersisa. Walaupun disebutkan potensi jenis Aquilaria di alam sudah sangat berkurang, khususnya $A$. malaccensis yang bahkan sudah masuk dalam jenis terancam punah, ternyata masih memiliki keragaman genetik yang cukup tinggi. Hal ini memungkinkan untuk dilakukan konservasi in-situ untuk jenis tersebut apabila jumlah individu dalam populasi tersebut masih memenuhi syarat dan kondisi lingkungannya masih mendukung.

Jarak genetik rata-rata antar populasi adalah 0,284 . Hal ini menunjukkan bahwa $71,6 \%$ distribusi dari keragaman genetik terletak di dalam populasi, sedangkan sisanya $28,4 \%$ adalah antar populasi. Jarak genetik populasi antar pulau lebih tinggi daripada antar populasi dalam pulau yang sama. Besarnya jarak genetik antar populasi juga digambarkan oleh pengelompokan populasi pada dendrogram (Gambar 1). Populasi yang secara geografis berdekatan akan membentuk kelompok yang sama.

Informasi keragaman tersebut menentukan pengambilan materi genetik untuk pembangunan plot konservasi eks-situ, baik jumlah populasi maupun individu di dalam populasi agar dapat tetap mempertahankan dasar keragaman genetik yang dimiliki. Setiap kelompok pada pengelompokan yang terjadi (Gambar 1) minimal diwakili oleh 1 populasi. Oleh karenanya, setiap pulau harus terwakili dan setiap propinsi dalam masing-masing pulau juga perlu diwakili oleh minimal satu populasi dengan jumlah individu dalam populasi yang cukup. Mengingat kedekatan hubungan antara $A$. malaccensis dan $A$. microcarpa, maka sebaiknya program konservasi keduanya dilakukan bersama-sama.

\section{KESIMPULAN}

1. Rata-rata keragaman genetik di dalam populasi dari 7 populasi Aquilaria spp. adalah 0,225. Keragaman terbesar dimiliki oleh populasi A. malaccensis asal Muara Bungo, Jambi $(0,285)$, sedangkan keragaman terendah dimiliki oleh populasi A. malaccensis Berau $(0,180)$.

2. Rata-rata jarak genetik antar populasi dari 7 populasi Aquilaria spp. adalah 0,284. Jarak genetik tertinggi yaitu antara populasi $A$. microcarpa Samboja dengan populasi $A$. beccariana Berau (0,494). Populasi $A$. microcarpa Berau dan populasi $A$. malaccensis Berau mempunyai jarak genetik terendah yaitu 0,017 .

3. Tujuh populasi terbagi menjadi 2 kelompok berdasarkan pulau. Pengelompokan untuk $A$. malaccensis dan $A$. microcarpa cenderung berdasarkan letak geografisnya dibandingkan kedekatan jenisnya. 


\section{DAFTAR PUSTAKA}

Carrio, E., Forrest, A. D., Guemes, J. dan Vargas, P. 2010. Evaluating species nonmonophyly as a trait affecting genetic diversity: a case study of three endangered species of Antirrhinum L. (Scrophulariaceae). Plant. Syst. Evol., 288:43-58

Hamrick, J. L 1989. Isozyme and The Analysis of Genetic Structure in Plant Population. In : Soltis, D.E and Soltis , P.S (Eds.) Isozyme in Plant Biology. Dioscorides Press, Oregon. pp 87-105

Hartati, D., Rimbawanto, A., Taryono, Sulistyaningsih, E. dan Widyatmoko, AYPBC. 2007. Pendugaan keragaman genetik di dalam dan antar provenan Pulai menggunakan penanda RAPD. Jurnal Pemuliaan Tanaman Hutan 1(2): 51-98.

Indrioko, S. 1996. Studi variasi genetik Pinus merkusii Jungh. et de Vriese di Pulau Jawa dengan metode analisis isozim. Tesis tidak diterbitkan. Fakultas Kehutanan Universitas Gajah Mada, Yogyakarta.

Murray, M. G. dan Thompson, W. F. 1980. Rapid isolation of high molecular weight plant DNA. Nuc. Acid. Res. 8:4321-4325.

Nei, M. 1978. Estimation of average heterozygosity and genetic distance from a small number of individuals. Genetics 89: 583-590.

Rimbawanto, A., Widyatmoko, AYPBC. dan Sulistyowati, P. 2006a. Distribusi Keragaman Genetik Populasi Santalum album berdasarkan penanda RAPD. Jurnal Penelitian Tanaman Hutan 3:175-181.

Rimbawanto, A. dan Widyatmoko, AYPBC. 2006. Keragaman genetik empat populasi Intsia bijuga berdasarkan penanda RAPD dan implikasinya bagi program konservasi genetik. Jurnal Penelitian Tanaman Hutan 3: $149-154$.
Rimbawanto, A., Widyatmoko, AYPBC. dan Harkingto. 2006b. Keragaman Populasi Eusideroxylon zwageri Kalimantan Timur berdasarkan penanda RAPD. Jurnal Penelitian Tanaman Hutan 3:201-208.

Shiraishi, S. dan Watanabe, A. 1995. Identification of chloroplast genome between Pinus densiflora Sieb. et Zucc. and $P$. thunbergii Parl. based on the polymorphism in rbcL gene. J. Jpn. For. Soc. 77: 429-436.

Sulistyawati, P., Widyatmoko, AYPBC. dan Rimbawanto, A. 2005. Keragaman genetik empat populasi Eusideroxylon zwageri asal Kalimantan berdasarkan penanda RAPD (Genetic variation of four populations of Eusideroxylon zwageri in Kalimantan revealed by RAPD markers). Dalam: Hardiyanto E.B. (ed). Prosiding Seminar Nasional Peningkatan Produktivitas HutanPeran Konservasi Sumber Daya Genetik, Pemuliaan dan Silvikultur dalam Mendukung Rehabilitasi Hutan. Fakultas Kehutanan UGM dan International Tropical Timber Organization.Yogyakarta. pp. 383395.

Welsh and McClelland, M. 1990. Fingerprinting Genomes Using PCR with Arbitary Primers. Nucleid Acids Research 18: 7213-7218.

Widyatmoko, AYPBC, Afrianti, R. D., Taryono dan Rimbawanto, A. 2009. Keragaman Genetik Lima Populasi Gyrinops versteegii di Lombok menggunakan Penanda RAPD. Jurnal Pemuliaan Tanaman Hutan 3:1-10.

Widyatmoko, AYPBC., Lejo, E. S. P., Prasetyaningsih, A. dan Rimbawanto, A. 2010. Keragaman genetik populasi Araucaria cunninghamii mengunakan penanda RAPD. Jurnal Pemuliaan Tanaman Hutan 4: 63-77. 
William, J. G. Z. K.,.Hanafey, M. K, Rafalsky, J. A. dan Tingey, S. V. 1993. Genetic Analisis Using Random Amplifide Polymorphic DNA markers. Methods enzymol. 218:704740.

Yeh, F.C., Yang, R. C., Boyle, T. B. J., Ye, Z. H. dan Mao, J. X.. 1999. POPGENE 3.2, The User-Friendly Shareware for Population Genetic Analysis. Molecular Biology and Biotechnology Center. University of Alberta. Edmonton. 